Bangladesh J. Bot. 50(3): 855-863, 2021 (September) SpecialＤOI: https://doi.org/10.3329/bjb.v50i5.56437

\title{
PHYTOPLANKTON IN RELATION TO PHYSICO-CHEMICAL FACTORS IN POYANG LAKE, JIANGXI
}

\author{
HaO DONG ${ }^{1,2,3,4}$ AND JiNBAO LiU ${ }^{1,2,3,4 *}$ \\ Shaanxi Provincial Land Engineering Construction Group Co. Ltd., \\ Xi'an, Shaanxi, 710075, China \\ Keywords: Poyang Lake, Phytoplankton, Community structure, Environmental factors, \\ Water quality evaluation
}

\begin{abstract}
Changes of phytoplankton structure and water quality were investigated in Poyang Lake from March 2014 to December 2019. The number of identified species in Poyang Lake was 187 belonging to 87 genera and 8 phyla (excluding undetermined species). Among them, Cyanophyta (74 species) had the maximum number of species, followed by Bacillariophyta (51 species) and Chlorophyta (36 species). The average numbers of phytoplankton cells were counted $2783.85 \pm 458.5 \times 10^{4}$ cells/l. A total of 20 dominant species were identified in Poyang Lake, including 6 of Cyanobacteria, 6 of Diatoms, 7 of Chlorophyta, 1 of Cryptophyta and 1 of Dinoflagellates. Among phytoplankton, Cyanophyta cell density was the highest, accounting for $91.06 \%$. Chlorophyta and diatoms accounted for 5.52 and $2.09 \%$, respectively. The cell density of Xanthophyta was the lowest, accounting for only $0.03 \%$. The four seasons showed obvious changes, and the order was summer - autumn - spring - winter. Algae were the most common, including green algae $153(53 \%)$, diatoms $74(26 \%)$, cyanobacteria $17(17 \%)$, similar to other domestic studies.
\end{abstract}

\section{Introduction}

The water system of Poyang Lake is the largest fresh water lake in China, with a total basin area of about 3,210 sq. km. (Qian et al. 2016). Protecting the "clean water of one lake" of Poyang Lake is a national demand to guarantee the ecological and environmental security of China and strengthening the research on the ecological environment of Poyang Lake is an urgent demand for the sustainable economic development of Jiangxi Province (Wang et al. 2021). With the rapid economic development in the Poyang Lake Basin, large number of industrial and agricultural wastewater and domestic sewage have been discharged from the surrounding areas, leading to changes in the water environment of Poyang Lake (Pu and Lin 2021). Nitrogen and phosphorus content in the water has increased sharply, leading to rapid growth of some phytoplankton and frequent phytoplankton outbreaks in the eutrophic water bodies (Yang et al. 2020).

Phytoplankton play the role of primary producer in aquatic food chain and are important indicator of ecosystem health and integrity. However, due to the massive proliferation of phytoplankton, both the physico-chemical factors and phytoplankton in Poyang Lake are in the eutrophication stage, and the availability of phytoplankton in Poyang Lake is constantly changing and in an unstable stage. It is important to know when the blooms of phytoplankton occur.

From the first field survey to the present experiment time, phytoplankton research in Poyang Lake can be divided into four stages: The initial stage of phytoplankton research (before 1985), the stage of quantitative investigation of phytoplankton community (1985-1999), the stage of

\footnotetext{
*Author for correspondence: <jinbaoliu@xaut.edu.cn>. ${ }^{1}$ Institute of Shaanxi Land Engineering Construction Group Co., Ltd., Xi'an 710075, China. ${ }^{2}$ Key Laboratory of Degraded and Unused Land Consolidation Engineering, Ministry of Land and Resources, Xi'an, China. ${ }^{3}$ Shaanxi Provincial Land Consolidation Engineering Technology Research Center, Xi'an, China. ${ }^{4}$ Land Engineering Technology Innovation Center, Ministry of Natural Resources, Xi'an, China.
} 
phytoplankton community model (1999-2005), the stage of phytoplankton community classification system/eutrophication evaluation (2005-2012), the combination of phytoplankton community structure and lake management policy formulation Phase (2012-present time) (Li and Chen 2020, Liu et al. 2020).

The present study aimed to study the phytoplankton community structure, physico-chemical properties and the correlation with environmental factors in Poyang lake from March 2014 to December 2019, and to analyze the cell density of phytoplankton species in different seasons (Jia et al. 2020). It would provide basic information and reference system for evaluating the effect of lake restoration and management, ecotourism and ecological island construction, and provide firsthand information for evaluating the possibility of ecosystem change.

\section{Materials and Methods}

Poyang lake is the largest freshwater lake, and located in the middle reaches of the Yangtze River in China. Its geographical coordinates are $28^{\circ} 52^{\prime} 05^{\prime \prime} \mathrm{N}-29^{\circ} 06^{\prime} 50^{\prime \prime} \mathrm{N}, 116^{\circ} 10^{\prime} 33^{\prime \prime} \mathrm{E}-$ $116^{\circ} 25^{\prime} 05^{\prime \prime} \mathrm{E}$ from March 2014 to December 2019. The sampling points are shown in Fig. 1. Samples were taken once a month in the second half of the month. Physical and chemical factors were measured on site, and indexes such as $\mathrm{pH}$ of water, temperature, dissolved oxygen and conductivity were measured with HQD series portable instrument produced by Hach Company (Zhang et al. 2019). Transparency was measured with Sachter's disk, and water depth was measured with HONDEX sonar depth sounder made by Hama Company in Japan. At the same time, 1L water sample was collected and brought back to the laboratory with Hach DR3900. The indexes of total nitrogen, total phosphorus, permanganate, ammonia, nitrogen, nitrite and nitrate were determined by the instrument (Wu et al. 2019).

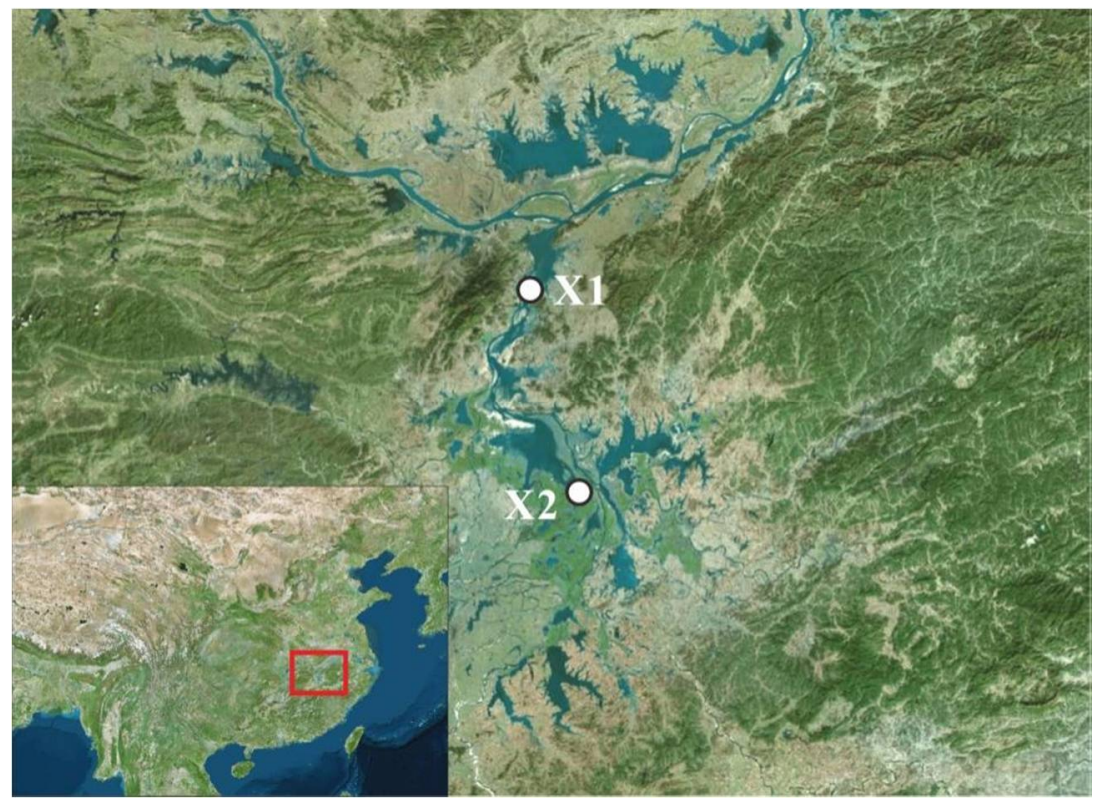

Fig. 1. Sampling site of Poyang Lake. 
The sample was fixed in a $50 \mathrm{ml}$ tube with $2 \%$ Lugol solution to determine the phytoplankton population. After fixing the reagent for $24 \mathrm{hrs,} \mathrm{Sedgwick} \mathrm{-} \mathrm{Raffter} \mathrm{Chamber} \mathrm{was} \mathrm{used} \mathrm{for} \mathrm{light}$ microscopy (Nikon Eclipse NI, Japan); four groups of phytoplankton, namely cyanobacteria, chlorobacteria, diatoms, and dinoflagellates were observed, divided into taxonomic star cell analysis and taxonomic military analysis (Cao et al. 2018, Liu et al. 2019). A number of water quality monitors (YSI 5700, YSI Inc., USA) were used for on-site measurement of water temperature, $\mathrm{pH}, \mathrm{DO}$, and electrical conductivity. Samples obtained on site were refrigerated and sent to the laboratory for water quality analysis as soon as possible. T-N, T-P, BOD, COD, SS, $\mathrm{NO}_{3}-\mathrm{N}, \mathrm{NH}_{3}-\mathrm{N}, \mathrm{PO}_{4}-\mathrm{P}$ and Chl-a were analyzed according to the Water Pollution Process Test Standard. Water quality data were analyzed at each study site in order to study the variability between the sites ( Qu et al. 2018, Ding et al. 2019). The statistical analysis of the relationship between phytoplankton and water quality factors in this study was SPSS 12.0 which was used for Pearson correlation analysis. The data of temperature and rainfall were collected from Jiangxi meteorological stations of National Climatic Data Center.

\section{Results and Discussion}

Monthly changes of precipitation and average temperature in Jiangxi Climate Data Center of meteorological station from 2014 to 2019 are presented in Fig. 2. The maximum precipitation in 2016 was $1,626.8 \mathrm{~mm}$, while the minimum precipitation in 2019 was $1100.1 \mathrm{~mm}$, a difference of $526.7 \mathrm{~mm}$. In six years, precipitation from June to September accounted for $54 \%$ of the annual precipitation, while in 2019 , the precipitation was less than $50 \%$, only $42 \%$. The average temperature was $14.7^{\circ} \mathrm{C}$ degrees in 2019 and $13.8^{\circ} \mathrm{C}$ in 2015 , with a difference of about $1^{\circ} \mathrm{C}$.

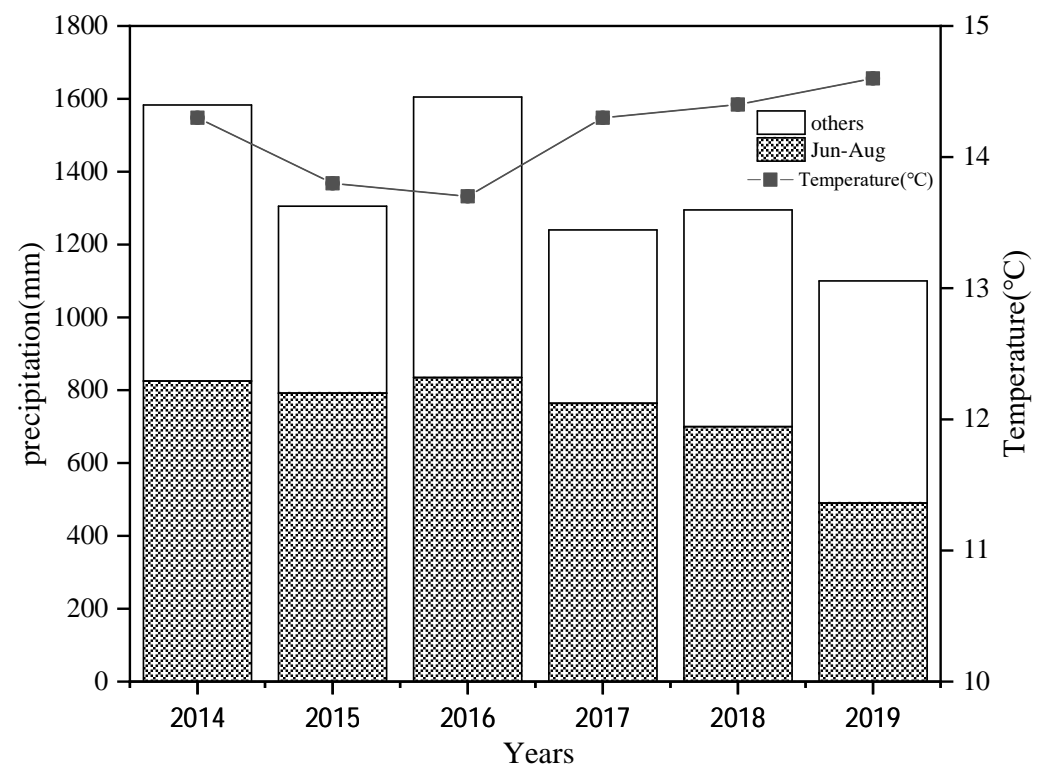

Fig. 2. Variation in annual total precipitation and temperature on Poyang Lake.

The annual change rates of water temperature, DO, pH, Chl- $a$, T-N, T-P, BOD, COD, SS, turbidity, $\mathrm{NO}_{3}-\mathrm{N}, \mathrm{NH}_{3}-\mathrm{N}$ and $\mathrm{PO}_{4}-\mathrm{P}$ for 6 years are shown in Table 1 . The annual mean water temperature was similar from 2015 to 2019 , being 13.8 and $14.7^{\circ} \mathrm{C}$, respectively (except for 2014). 


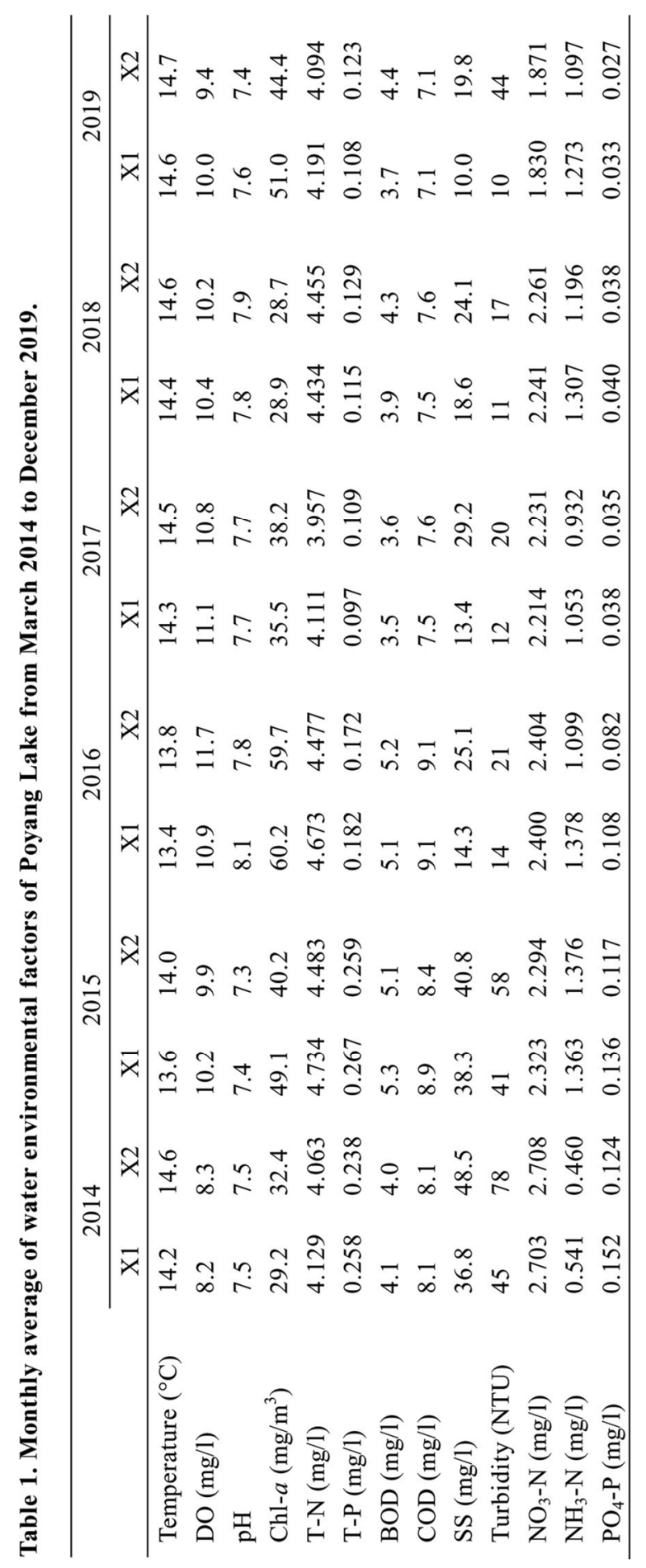


There was little change from 2015 to 2019 , and the temperature in 2019 was slightly higher than that in the previous year. The range of dissolved oxygen was between 3.7 and $17.6 \mathrm{mg} / \mathrm{l}$, with an increasing trend in summer. Except for 2016, it was below $8 \mathrm{mg} / \mathrm{l}$ in summer. The average dissolved oxygen was $10.0 \mathrm{mg} / \mathrm{l}$, and the average annual Ia level of the environmental water standard was maintained during the 6 years. $\mathrm{pH}$ values were found to range from 6.2 to 9.1 , with an average of 7.6, similar to previous studies of 6.7 and 7.4. The $\mathrm{pH}$ value of 2014 increased continuously from 2014 to 2016 , and then gradually decreased to the level of 2015, both of which showed certain performance.

T-N ranged from 1.749 to $9.916 \mathrm{mg} / \mathrm{l}$, and continued to decrease from January to September, but showed an upward trend after September. In 2015 and 2016, the highest values in winter and spring were 0.570 and $0.695 \mathrm{mg} / \mathrm{l}$, respectively and in 2017 and 2019 , the average values were 0.106 and $0.120 \mathrm{mg} / \mathrm{l}$, respectively which showed a decreasing trend. This might be due to the large-scale manual processing facility carried out in October 2016. The average BOD at these two points was $4.3 \mathrm{mg} / \mathrm{l}$, ranging from 1.3 to $11.6 \mathrm{mg} / \mathrm{l}$. Except for 2015, high records were generally recorded in July. The average COD of the two points was $7.9 \mathrm{mg} / \mathrm{l}$, and the range was $2.5 \sim 16.4$ mg/l. SS and turbidity showed no significant changes except in 2014 and 2015. In 2014 and 2015, the average value caused by the project was on the high side, and the further downstream, the higher the average value. After 2016, the change of meters was found to increase in July and August. The mean values of $\mathrm{NO}_{3}-\mathrm{N}$ at these two points were $2.290 \mathrm{mg} / \mathrm{l}$ and between 0.789 and $4.530 \mathrm{mg} / \mathrm{l}$, high in winter and low in summer, and both have declined since 2014. Like $\mathrm{NO}_{3}-\mathrm{N}$, $\mathrm{NH}_{3}-\mathrm{N}$ has a higher value in winter and a higher value in the downstream, ranging from 0.026 to $5.737 \mathrm{mg} / \mathrm{l}$. The mean value of $\mathrm{PO}_{4}-\mathrm{P}$ at two points was $0.078 \mathrm{mg} / \mathrm{l}$, ranging from 0.001 to 0.384 $\mathrm{mg} / \mathrm{l}$, and continued to decrease since 2016. Similar to T-P, this might be due to the establishment of total phosphorus treatment facilities. Although nutrients such as $\mathrm{PO}_{4}-\mathrm{P}$ were reduced after the construction of the dam, the reduction of turbidity also led to the formation of algae in the water system (Chen and Chen 2015). Poyang lake has a large drainage area, but its main branches are narrow and are greatly affected by rainfall. Point sources are located near the main streams, which undergo rapid physical and chemical changes. It indicates that the tidal current of Poyang Lake is more sensitive to the change of water environment factors than physical factors, and its community structure and available water amount change.

A total of 20 dominant species were identified in Poyang Lake, including 6 of Cyanobacteria, 6 of Diatoms, 7 of Chlorophyta, 1 of Cryptophyta and 1 of Dinoflagellates. Among phytoplankton, Cyanophyta cell density was the highest, accounting for 91.06\%. Chlorophyta and diatoms accounted for 5.52 and $2.09 \%$, respectively. The cell density of Xanthophyta was the lowest, accounting for only $0.03 \%$. The four seasons showed obvious changes, and the order was summer - autumn - spring - winter.

Monthly variation of number of phytoplankton species presented in Fig. 2 showed that there was in total 288 species in the studied take. A total of 83 species were identified in 2014, including 7 cyanobacteria (8\%), 27 diatoms (33\%), 34 chlorophyta (41\%) and 15 others (18\%). A total of 114 species were identified in 2015, including 9 cyanobacteria (8\%), 27 diatoms (24\%), 61 chlorobacteria (54\%) and 17 others (15\%). A total of 114 species were identified in 2016, including 9 cyanobacteria (8\%), 57 diatoms (22\%), 62 chlorobacteria (54\%) and 18 others (16\%). A total of 115 species were identified in 2017, including 10 cyanobacteria (9\%), 32 diatoms (28\%), 57 chlorobacteria (50\%) and 16 others (14\%). A total of 131 species were identified in 2018, including 8 cyanobacteria (6\%), 39 diatoms (30\%), 65 chlorobacteria (50\%) and 19 others $(15 \%)$. A total of 163 species were identified in 2019, including 7 cyanobacteria (4\%), 49 diatoms (30\%), 76 chlorophyta (47\%) and 31 others (19\%). There were as many as 34 species in 2014 and 61 species of cyanobacteria in 2015 , which doubled and increased, and then showed a similar 
level. Compared with 2014, the total number of cyanobacteria species in 2019 increased by about two times, presenting a variety of species on the whole, which is the difference of survey frequency and season.

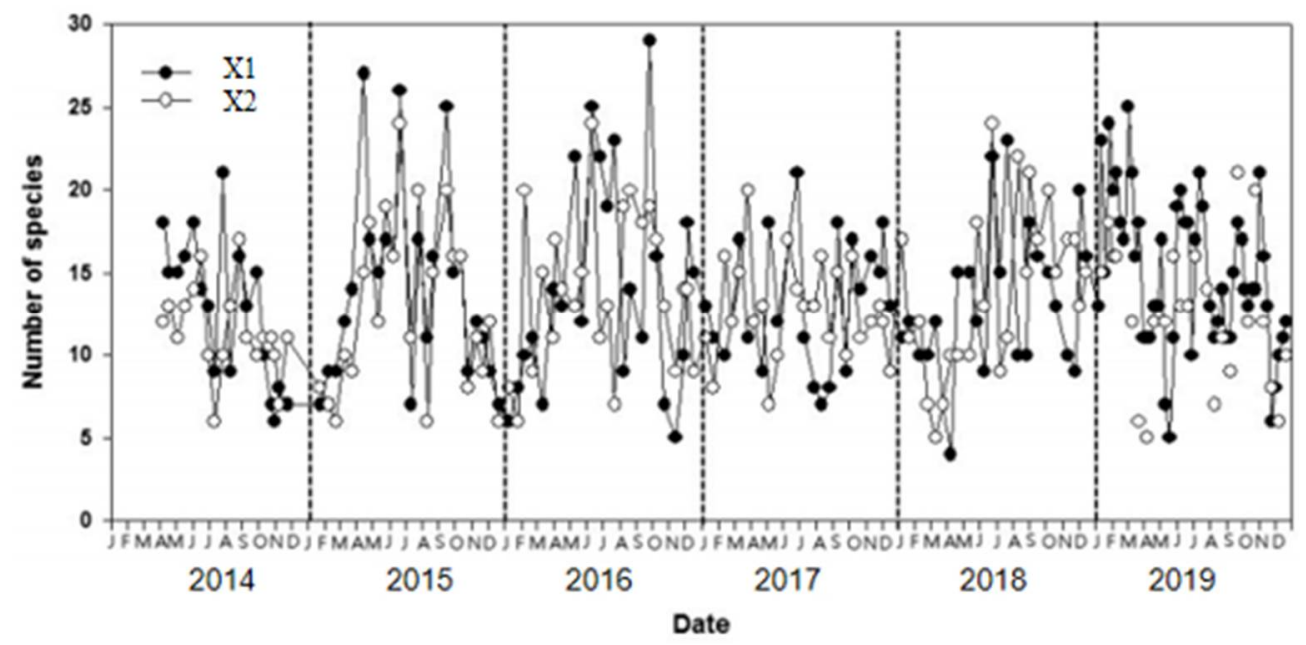

Fig.2. Monthly variation of number of species in Poyang Lake.

In the past 6 years, the number of diatoms was low because of the increase of the dominance in winter and spring, but the dominance of green algae and other algae decreased after December, while the number of diatoms increased. The change of the number of diatoms was different with the different dominance. When the summer comes, the number of species decreases, which is the advantage of cyanobacteria, and then increases in the autumn. The values of the two sites showed that the upstream sites with lower dominance points had more species of Y1. The species of X1 point ranged from 4 species (December 2018) to 29 species (September 2016), and the species of X2 point ranged from 5 species (December 2019) to 24 species (June 2018).

Over the course of six years of the study, dominant genera included Cyclotella sp., Stephanodiscus sp., Aulacoseira sp., Skeletonema sp., Nitzschia sp., Synedra sp., Melosira sp., Pandorina sp., Micractinium sp., Actinastrum sp., Pediastrum sp., Coelastrum sp., Eudorina sp. Among the genera Cryptomonas (Table 2), the Tephanodiscus sp. and Aulacoseira sp. had the maximum dominant periods. The dominant period of harmful algae changes every year. In 6 years, the proportion of algae stocks is 13\%; and this reaches the maximum of $95 \%$ in 2019 in late summer when the water temperature is higher than $25^{\circ} \mathrm{C}$, which is the dominant period.

Temperature is one of the important factors for phytoplankton reproduction in water, which has a great influence on the growth of phytoplankton. Different phytoplankton have their own optimum growth temperature. In 2007, Liu et al. studied the phytoplankton community structure in Poyang Lake and found that the phytoplankton cell density and biomass were positively correlated with water temperature. Similarly, with the increase of water temperature from 2015 to 2019, both the cell density and biomass of cyanobacteria increased. Compared with other phytoplankton, cyanobacteria had stronger tolerance to higher temperature, the optimal growth temperature of cyanobacteria was $25-30^{\circ} \mathrm{C}$, the optimal growth temperature of chlorophyta was $20-25^{\circ} \mathrm{C}$, and the optimal growth temperature of diatoms was $14-18^{\circ} \mathrm{C}$. Microcystis sp. of 


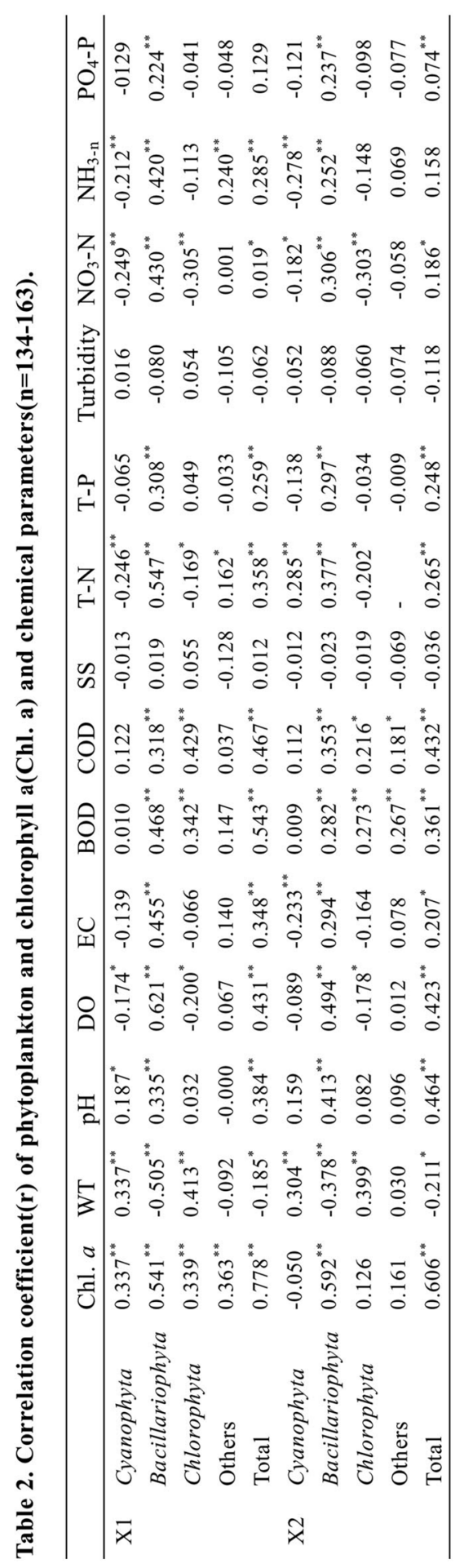


cyanobacteria could still grow normally at water temperature greater than $35^{\circ} \mathrm{C}$. Other studies have shown that cyanobacteria generally have a growth advantage when the water temperature exceeds $20^{\circ} \mathrm{C}$. From 2015 to 2019 , the average annual water temperature showed an increasing trend, which had a certain impact on the temperature-sensitive phytoplankton. For example, the species of Cyanobacteria positively correlated with temperature indicating that the species of Cyanobacteria in this study were richer and more diverse than that in 2014.

Correlation analysis of Poyang Lake data at two points showed that phytoplankton stocks at two points were significantly correlated with Chl- $a, \mathrm{pH}, \mathrm{DO}, \mathrm{EC}, \mathrm{BOD}, \mathrm{COD}, \mathrm{T}-\mathrm{N}, \mathrm{T}-\mathrm{P}$, and WT but was negatively correlated with turbidity (Table 2). The annual average storage of point X1 ranged from 4,387 to $14,677 \mathrm{cells} / \mathrm{ml}$, and the average storage in 2016 was 14,677 cells $/ \mathrm{ml}$. The annual average storage capacity of X2 was 3,361-17,347 cells $/ \mathrm{ml}$, the same as that of X1, which peaked at 17,347 cells $/ \mathrm{ml}$ in 2016.It was from January to March that the temperature began to significantly affect the growth of algae, which was consistent with previous studies.

From March 2014 to December 2019, water quality and phytoplankton changes in the upper and lower reaches of Poyang Lake were studied. During the same period, the average water temperature at both sites was $18.2^{\circ} \mathrm{C}$, which remained at $16.3^{\circ} \mathrm{C}$ from 2014 to 2019 and rose by 0.7 to $17.3^{\circ} \mathrm{C}$ in 2015 . During the survey period, phytoplankton species composition was divided into 288 groups, including 17 groups of cyanobacteria, 74 groups of diatoms and 154 groups of green algae. The population densities of these two sites ranged from 500 to $29,950 \mathrm{cells} / \mathrm{ml}$, at X1 from 850 to 29,725 cells $/ \mathrm{ml}$, and at X2 from 500 to $29,950 \mathrm{cells} / \mathrm{ml}$. The mean densities of the two points at the upstream point were shown to be 8,180 cells $/ \mathrm{ml}$ and 7,530 cells $/ \mathrm{ml}$ at X2. Among the dominant species are the very high Stephanodiscus, with a dominant frequency of 59\% compared to $22 \%$ for Rhombus. The dominant frequency of cyanobacteria on the whole was $17 \%$, X1 was $19 \%$, which was $2 \%$ higher than X2. Among them, the dominant frequency of Microcystis was $6 \%$, while the dominant frequency of $\mathrm{X} 1$ locus was $7 \%$, which was $2 \%$ higher than that of downstream X2 locus. The stock proportion of X1 point was as follows: diatoms accounted for $52 \%$, green algae for $24 \%$ and cyanobacteria for $21 \%$ of the total; At X2, $65 \%$ of diatoms, $18 \%$ of green algae and $13 \%$ of cyanobacteria were found, indicating that the stock proportion of cyanobacteria upstream of X1 point was higher. The purpose of this study was to understand the phenomenon of phytoplankton drift and the reasons for the change of water quality factors, and to provide reliable data for the characteristics of Poyang Lake, which will provide basic data for the evaluation of aquatic ecosystem changes in future.

\section{Acknowledgements}

This work was financially supported by Shaanxi Provincial Land Engineering Construction Group fund (DJNY-2021-38).

\section{References}

Cao J, Hou Z, Li Z, Chu Z, Yang P and Zheng B 2018. Succession of phytoplankton functional groups and their driving factors in a subtropical plateau lake. Sci. Total Environ. 631-632, 1127-1137.

Chen S-H and Chen L-J 2015. Liquid-liquid equilibria for the ternary system water+octane+2-butyloxyethanol. Fluid Phase Equilibria 399: 16-21.

Ding Y, Wang S, Zhang W, Feng M and Yu R 2019. A rule of hydrological regulating on nutritional status of Poyang Lake, since the operation of the Three Gorges Dam. Ecol. Indicators 104: 535-542.

Jia J, Gao Y, Zhou F, Shi K, Johnes PJ, Dungait JAJ, Ma M and Lu Y 2020. Identifying the main drivers of change of phytoplankton community structure and gross primary productivity in a river-lake system. J. Hydrology 583:124633. 
Li Y and Chen F 2020. Are zooplankton useful indicators of water quality in subtropical lakes with high human impacts? Ecol. Indicat. 113: 106167.

Liu H, Zhou W, Li X, Chu Q, Tang N, Shu B, Liu G and Xing W 2020. How many submerged macrophyte species are needed to improve water clarity and quality in Yangtze floodplain lakes? Sci. Total Environ. 724: 138267.

Liu J, Chen Y, Li M, Liu B, Liu X, Wu Z, Cai Y, Xu J and Wang J 2019. Water-level fluctuations are key for phytoplankton taxonomic communities and functional groups in Poyang Lake. Ecol. Indicat. 104: 470478.

Liu K-K, Chen Y-J, Tseng C-M, Lin I-I, Liu H-B and Snidvongs A 2007. The significance of phytoplankton photo-adaptation and benthic-pelagic coupling to primary production in the South China Sea: Observations and numerical investigations. Deep Sea Research Part II: Top. Stud. Oceanogr. 54(14-15): 1546-1574.

$\mathrm{Pu} \mathrm{L}$ and Lin Z 2021. Effects of depth and evolving rate on phytoplankton growth in a periodically evolving environment. J. Math. Anal. Applicat. 493(1): 124502.

Qian K, Liu X and Chen Y 2016. Effects of water level fluctuation on phytoplankton succession in Poyang Lake, China - A five year study. Ecohydrol. Hydrobiol. 16(3): 175-184.

Qu Y, Wu N, Guse B and Fohrer N 2018. Riverine phytoplankton shifting along a lentic-lotic continuum under hydrological, physiochemical conditions and species dispersal. Sci. Total Environ. 619-620, 16281636.

Wang S, Gao Y, Jia J, Kun S, Lyu S, Li Z, Lu Y and Wen X 2021. Water level as the key controlling regulator associated with nutrient and gross primary productivity changes in a large floodplain-lake system (Lake Poyang), China. J. Hydrol. 599: 126414.

Wu Z, Liu J, Huang J, Cai Y, Chen Y and Li K 2019. Do the key factors determining phytoplankton growth change with water level in China's largest freshwater lake? Ecol. Indicat. 107: 105675.

Yang Y, Chen J, Tong T, Xie S and Liu Y 2020. Influences of eutrophication on methanogenesis pathways and methanogenic microbial community structures in freshwater lakes. Environ. Poll. 260: 114106.

Zhang K, Jiang F, Chen H, Dibar DT, Wu Q and Zhou Z 2019. Temporal and spatial variations in zooplankton communities in relation to environmental factors in four floodplain lakes located in the middle reach of the Yangtze River, China. Environ. Poll. 251: 277-284.

(Manuscript received on 22 June, 2021; revised on 27 August, 2021) 